\title{
Impact of Training and Demonstration on Integrated Crop Management in Transplanted Paddy in Chamarajanagar District of Karnataka, India
}

\author{
C.M Sunil*, Chandrakala Hanagi* and G.S. Yogesh*
}

\begin{abstract}
Altogether, 11 practices were selected as criteria to evaluate the farmers on the extent of knowledge gained and adoption of rice production technologies as a result of training programmes conducted by Krishi Vigyan Kendra in Chamarajanagar district of Karnataka. The study revealed that the knowledge gained by farmers about the production technologies for rice ranged from $0 \%$ (mechanical harvesting) to $100 \%$ (hybrid variety and weed management). The adoption of hybrid rice variety $\mathrm{KRH}-4$ was $100 \%$ The results indicate that there are greater possibilities of increasing productivity and profitability of the rice crop with adoption of improved techniques in Chamarajanagar district of Karnataka, India.
\end{abstract}

Keywords : Training; Demonstration; Paddy; Karnataka

In India, rice is the most important and extensively grown food crop. India is still amongst the countries with the lowest rice yields. Seventy percent of all rice growing districts report yields lower than the national average. Yield gap analysis reveals that 3040 per cent of the potential yield is yet to be tapped with available high yielding varieties (HYV) with improved practices. The area, production and productivity of Karnataka was $1.01 \mathrm{~m}$. ha., $2.54 \mathrm{~m}$. t. and $25.22 \mathrm{q} / \mathrm{ha}$, respectively (Anonymous, 2018).

The geographical area of Chamarajanagar district is about $5,101 \mathrm{Km}^{2}$. It is situated in the Southern dry zone (Zone
6) of the state. Most of the district lies in the leeward region of the Nilgiris and consists of mainly semi- arid rain-dependent flatlands along with forested hills. The district has five taluks viz., Chamarajanagara, Gundlupet, Kollegal, Yellandur and Hanuru.

Chamarajanagar district is known for its varied agro-climatic conditions with diversified cropping situation. Around 50 per cent of the cropped area is under cereals and 22 per cent under pulses. Thus food crops cover almost three fourths (73 per cent) of the cropped area. Paddy is an important cereal crop having an area of 18806 ha under Kabini command area with a productivity

\footnotetext{
*ICAR- Krishi Vigyan Kendra, Chamarajanagar District, Karnataka-571127. India

Received : 03-05-2021; Accepted : 28-05-2021
} 
Impact of Training and Demonstration on Integrated Crop Management in Transplanted Paddy in Chamarajanagar District of Karnataka, India

of $47.80 \mathrm{q} / \mathrm{ha}$ and the yield gap is $37.20 \mathrm{q} /$ ha (Anonymous, 2018). This yield gap is possibly due to use of local varieties, higher seed rate plant population, non-adoption of seed treatment with bioagents and biofertilizers, lack of knowledge on chemical weed management, unavailability of labour for timely weeding, low input use efficiency, low water use efficiency, lack of knowledge on integrated pest and disease management practices and no knowledge about post harvest management technologies. With this background the present study was designed.

\section{METHODOLOGY}

The study was carried out through conducting training programmes, method demonstrations and front line demonstrations (8 ha for 20 farmers) during kharif 2018 and 2019 in two villages viz., Y.K. Moleand Irasavadi of Chamarajanagar district of Karnataka state for dissemination and popularization of technologies. Before demonstration, group meetings were conducted in each village where the problem prevailed with respect to production technologies. A list of interested farmers was prepared from the meeting. Further, training programmes were organized involving the selected farmers and pre and post evaluation was done to work out the change in knowledge and adoption level of beneficiaries and expressed in percentage.

The package of improved technologies like line planting, integrated nutrient management including micro nutrient application (Zinc sulphate), integrated weed management, water management, seed treatment with systemic insecticides,
Azospirillum and PSB (Phosphate Solubilising Bacteria) and the whole package was demonstrated. Along with that, the field days and other extension activities were organized inviting the farmers from nearby villages.

Further, statistical analysis (Student $\mathrm{t}$ test for two mean) was done for grain yield to check the level of significance (Das and Giri, 1988). The technology gap, extension gap and the technology index were calculated by adopting suitable formulae (Naik et al., 2015). Extension gap $=$ Demonstration yield - Farmers' practice yield, Technology gap $=$ Potential yield - Demonstration yield, Technology index $=$ Potential yield - Demonstration yield/ Potential yield $x$ 100. Finally, economics assessment was done as per prevailing market prices. Cost of cultivation, Gross returns, net returns and $\mathrm{B}: \mathrm{C}$ ratio were calculated as per the procedure outlined by Saravanakumar (2021).

\section{FINDINGS AND DISICUSSION}

\section{Impact of Training Programme on Gain in Knowledge level of Beneficiaries}

Skill training programmes play a crucial role in gaining the knowledge about the technology by farmers. The results pertaining to the change in knowledge level are presented in Table -1. The change in knowledge level of farmers on rice production technologies after attending the training programme ranges from $0.00 \%$ (mechanical harvesting) to $100 \%$ (hybrid variety and weed management). Highest knowledge gain was on $\mathrm{KRH}-4$ hybrid variety (100\%) and weed management practices (100\%) followed by Seed treatment 
Table 1.

Impact of Training Programme on gain in Knowledge level of Beneficiaries

\begin{tabular}{|c|c|c|c|c|c|c|c|}
\hline \multirow[b]{2}{*}{$\begin{array}{l}\text { Sl. } \\
\text { No. }\end{array}$} & \multirow[b]{2}{*}{ Improved technology } & \multicolumn{4}{|c|}{ Knowledge level of Trainees } & \multirow{2}{*}{$\begin{array}{c}\text { Gain in knowledge } \\
\text { level }\end{array}$} & \multirow[b]{2}{*}{ Rank } \\
\hline & & $\begin{array}{l}\text { Before } \\
\text { training }\end{array}$ & Rank & $\begin{array}{c}\text { After } \\
\text { training }\end{array}$ & Rank & & \\
\hline 1 & Land Preparation & $15(75.0)$ & 1 & $18(90.0)$ & III & $03(15.0)$ & VII \\
\hline 2 & Green manuring & $04(20.0)$ & $\mathrm{VI}$ & $16(80.0)$ & V & $12(60.0)$ & IV \\
\hline 3 & $\mathrm{KRH}-4$ hybrid & $00(0.00)$ & VIII & $20(100.0)$ & 1 & $20(100.0)$ & 1 \\
\hline 4 & Seed rate & $05(25.0)$ & $\mathrm{V}$ & $17(85.0)$ & IV & $12(60.0)$ & IV \\
\hline 5 & Seed treatment & $00(0.00)$ & VIII & $12.0(60.0)$ & IX & $18(90.0)$ & II \\
\hline 6 & Establishment method & $02(10.0)$ & VII & $17(85.0)$ & IV & $18(90.0)$ & II \\
\hline 7 & Nutrient management & $07(30.5)$ & IV & $15(75.0)$ & VI & $08(40.0)$ & $\mathrm{V}$ \\
\hline 8 & Water management & $02(10.0)$ & VII & $19(95.0)$ & II & $17(85.0)$ & III \\
\hline 9 & Weed management & $0(0.00)$ & VIII & $20(100.0)$ & $\mathrm{I}$ & $20(100.0)$ & $\mathrm{I}$ \\
\hline 10 & Plant protection & $08(40.0)$ & III & $13(65.0)$ & VIII & $05(25.0)$ & $\mathrm{VI}$ \\
\hline 11 & Mechanical harvesting & $14(70.0)$ & II & $14(70.0)$ & VII & $00(0.00)$ & VIII \\
\hline
\end{tabular}

Note: Figures in parentheses indicate percentage

(90.0\%), establishment method (90\%), water management (85.0\%), green manuring $(60 \%)$, seed rate $(60 \%)$, Nutrient management $(40.0 \%)$, plant protection (25.0), land preparation (15.0\%) and Mechanical harvesting(0\%). Singh et al. (2014) had mentioned that this might be due to better understanding of subject in a simple way by beneficiaries as a result of better organizing of training programmes and method demonstration.

\section{Impact of Training Programme on Adoption Level of Beneficiaries}

The results pertaining to adoption level of beneficiaries are presented in Table- 2 . The data revealed that most of the farmers were growing local varieties (100\%), did not adopt seed treatment (100\%), traditional establishment methods i.e., 20-30 days old seedlings transplanted @ 3-5 seedlings (90.0\%), poor water management (90.0\%), higher seed rate $(85.0 \%)$, less rate of green manure application (80\%), poor nutrient management (75\%), injudicious usage of plant protection chemicals (75\%), poor land preparation (35\%) and less usage of machinery in harvesting (30\%) before acquiring the training. Whereas, after attending the training programme, 100 percent of the beneficiaries adopted high yielding $\mathrm{KRH}-4$ Hybrid rice variety, proper weed management practices (85.0\%), growing green manuring crops (55\%), establishment method i.e., transplanting of 20-25 days age old seedling @ 1-2 seedlings per hill (55\%), recommended seed rate (50\%), adopting seed treatment $(50 \%)$, proper water management technologies (35.0\%), recommended and need based plant protection chemicals usage 
Impact of Training and Demonstration on Integrated Crop Management in Transplanted Paddy in Chamarajanagar District of Karnataka, India

Table 2.

Impact of Training Programme on Adoption Level of Beneficiaries

\begin{tabular}{|c|l|c|c|c|c|c|c|}
\hline \multirow{2}{*}{$\begin{array}{c}\text { SI. } \\
\text { No. }\end{array}$} & \multirow{2}{*}{ Improved technology } & \multicolumn{3}{|c|}{ Adoption level of Trainees } & \multirow{2}{*}{$\begin{array}{c}\text { Gain in } \\
\text { adoption level }\end{array}$} & Rank \\
\cline { 3 - 6 } & $\begin{array}{c}\text { Before } \\
\text { training }\end{array}$ & Rank & $\begin{array}{c}\text { After } \\
\text { training }\end{array}$ & Rank & \\
\hline 1 & Land Preparation & $13(65.0)$ & II & $16(80.0)$ & III & $03(15.0)$ & VIII \\
\hline 2 & Green manuring & $04(20.0)$ & IV & $15(75.0)$ & IV & $11(55.0)$ & III \\
\hline 3 & KRH-4 hybrid & $00(0.00)$ & VII & $20(100.0)$ & I & $20(100.0)$ & I \\
\hline 4 & Seed rate & $03(15.0)$ & $\mathrm{V}$ & $13(65.0)$ & VI & $10(50.0)$ & IV \\
\hline 5 & Seed treatment & $00(0.00)$ & $\mathrm{VII}$ & $10(50.0)$ & $\mathrm{IX}$ & $10(50.0)$ & $\mathrm{IV}$ \\
\hline 6 & Establishment method & $02(10.0)$ & $\mathrm{VI}$ & $13(65.0)$ & $\mathrm{VI}$ & $11(55.0)$ & $\mathrm{III}$ \\
\hline 7 & Nutrient management & $05(25.0)$ & $\mathrm{III}$ & $12(60.0)$ & $\mathrm{VII}$ & $07(35.0)$ & $\mathrm{VI}$ \\
\hline 8 & Water Management & $02(10.0)$ & $\mathrm{VI}$ & $11(55.0)$ & $\mathrm{VIII}$ & $09(45.0)$ & $\mathrm{V}$ \\
\hline 9 & Weed management & $00(0.00)$ & $\mathrm{VII}$ & $17(85.0)$ & $\mathrm{II}$ & $17(85.0)$ & $\mathrm{II}$ \\
\hline 10 & Plant protection & $05(25.0)$ & $\mathrm{III}$ & $11(55.0)$ & $\mathrm{VIII}$ & $06(30.0)$ & $\mathrm{VII}$ \\
\hline 11 & Mechanical harvesting & $14(70.0)$ & $\mathrm{I}$ & $14(70.0)$ & $\mathrm{V}$ & $00(0.00)$ & $\mathrm{IX}$ \\
\hline
\end{tabular}

Note: Figures in parentheses indicate percentage

(30.0\%), proper land preparation (15.0\%) and less usage of mechanical harvesting (0.00). Adoption level of beneficiaries increased more than $50 \%$ with all the improved practices. These findings are in agreement with Singh et al. (2014).

Extension gap, Technology gap and Technology index

Data presented in Table-3 shows the variation in extension gap and it varied from 24.7 to $33.2 \mathrm{q} / \mathrm{ha}$. Variations in technology gap (12.0-12.5 q/ha) reflected the impact of recommended technologies used in front line demonstrations in subsequent years. Fluctuations in technology gap as observed may be due to several biotic and abiotic factors. Technology index showed the feasibility of the evolved technology at the farmers' fields. Variations in technology index during the FLDs were found to be 14.11 - 14.70\%. (Table-3) This might be due to variations in soil fertility, environmental variation and infestation of pests.

Suggestions from FLD farmers for Improving Adoption of Technologies

- Farmers have requested to make available $\mathrm{KRH}-4$ hybrid rice under seed chain with subsidy as it is expensive to purchase directly from market.

- Farmers have requested to ensure easy availability of bio-fertilizers.

- New broad spectrum herbicide molecules recommended in package of practice 
Table 3.

Technological Gap Analysis of Frontline Demonstrations on Hybrid Paddy in Farmers' Fields

\begin{tabular}{|c|c|c|c|c|c|c|c|c|}
\hline \multirow[b]{2}{*}{$\begin{array}{l}\text { Sl. } \\
\text { No. }\end{array}$} & \multirow[b]{2}{*}{ Year } & \multirow[b]{2}{*}{$\begin{array}{l}\text { Area } \\
\text { (ha) }\end{array}$} & \multicolumn{3}{|c|}{ Grain yield (q/ha) } & \multirow{2}{*}{$\begin{array}{l}\text { Technology } \\
\text { Gap (q/ha) }\end{array}$} & \multirow{2}{*}{$\begin{array}{l}\text { Extension } \\
\text { Gap (q/ha) }\end{array}$} & \multirow{2}{*}{$\begin{array}{l}\text { Technology } \\
\text { Index (\%) }\end{array}$} \\
\hline & & & Potential & $\begin{array}{l}\text { Demonstra- } \\
\text { tion }\end{array}$ & Control & & & \\
\hline 1 & 2018-19 & 4.0 & 85.0 & 72.5 & 47.8 & 12.5 & 24.7 & 14.70 \\
\hline 2 & $2019-20$ & 4.0 & 85.0 & 73.0 & 39.8 & 12.0 & 33.2 & 14.11 \\
\hline \multicolumn{3}{|c|}{ Mean } & 85.0 & 72.75 & 43.8 & 12.25 & 28.95 & 14.41 \\
\hline
\end{tabular}

should be made available in nearby pesticide shops during the season.

- Development and easy availability of multi pest and disease tolerant varieties.

- Easy availability of seeds of green manuring crops like Daincha and sunhemp.

- Easy availability of quality organic manures

\section{REFERENCES}

Anonymous (2018). Chamarajangara district at a glance, Department of Statistics, Government of Karnataka.

Das, M.N \& Giri, N.C. (1988). Design and analysis of experiments. New International Private Limited Publishers (2nd Edition), New Delhi.
Naik, A, Patil, D.H, Siddappa \& Teggelli, R.G. (2015). Evaluation of Frontline Demonstration of Greengram (Vigna radiata L.) in Kalaburagi Region of Northern Karnataka. Trends in Biosciences 8(11): 2818-2820.

Saravanakumar, S. (2021). Evaluation of Frontline Demonstration on Wheat Crop in Western Zone of Tamil Nadu. Indian Research Journal of Extension Education 21(1):20-23.

Singh, A.P, Vaid, A \& Mahajan, V. (2014). Impact of $\mathrm{KVK}$ training programmes and front line demonstrations on adoption of Pusa Basmati 1121 in Kathua district of Jammu and Kashmir. Journal of Krishi Vigyan 2(2), 44-48. 